\title{
IN SITU NITROGEN FIXATION BY CYANOBACTERIA AT THE ANDRAGULLA CAVE, SPAIN
}

\author{
Antonia Dolores Asencio ${ }^{1}$ and Marina Aboal ${ }^{2}$
}

\begin{abstract}
Andragulla Cave is $2 \mathrm{~m}$ high, $6 \mathrm{~m}$ wide, and $2 \mathrm{~m}$ long (deep). Its lack of depth means that it is not isolated from external influences, and the microclimate is very similar to that experienced externally. The common stress factors on the growth of cyanobacterial communities on walls inside of Andragulla Cave include excess light, dryness, lack of nutrients, and cold temperatures. Nitrogen fixation, photon flux, relative humidity, and temperature in Andragulla Cave were measured hourly over 24 hours in winter. Nitrogen fixation by the reddish-brown mat formed by both cyanobacteria Scytonema mirabile and Gloeocapsa sanguinea in cave-like environments was measured in situ for the first time by acetylene reduction. The mat-specific rates (1.6 to $7.5 \mathrm{nmol} \mathrm{C}_{2} \mathrm{H}_{4}$ $\mathrm{m}^{-2} \mathrm{~s}^{-1}$ ) were lower compared to published values from laboratory measurements of rehydrated samples from different environments. Daytime fixation was slightly higher than nighttime fixation, where nitrogen fixation by Gloeocapsa sanguinea played an important role. The most influential parameters for environmental nitrogen fixation in Andragulla Cave were photon flux for daytime fixation, temperature for nighttime fixation, and relative humidity for both. Nitrogen fixation by cyanobacteria may be significant in these N-poor ecosystems.
\end{abstract}

\section{INTRODUCTION}

Atmospheric nitrogen fixation ability is limited exclusively to prokaryotes. Cyanobacteria are the only prokaryotes capable of both nitrogen fixation and oxygenic photosynthesis. The coexistence in a single organism of oxygenic photosynthesis and nitrogen fixation appears to be paradoxical, because nitrogen fixation is an intrinsically anaerobic process. The key enzyme involved, nitrogenase, is rapidly and irreversibly inactivated in vivo when exposed to even low oxygen partial pressures.

In heterocysted cyanobacteria, a spatial separation takes place between the incompatible nitrogen fixation and oxygenic photosynthesis processes. Even though heterocysts retain photosystem activity I, they lack photosystem II and activity of ribulose bisphosphate carboxylase, a fundamental enzyme in the Calvin cycle. Consequently, heterocysts are neither able to fix $\mathrm{CO}_{2}$ nor able to produce $\mathrm{O}_{2}$. They also have a special cellular casing that restricts oxygen from entering (Walsby, 1985). For this reason, heterocysts are practically anoxic inside and are nitrogen fixation sites (Fay, 1992).

It is likely that all heterocysted cyanobacteria are able to fix molecular nitrogen (Gallon, 1980). When other compounds of nitrogen are limited, using atmospheric nitrogen gives a competitive advantage over those organisms lacking nitrogenase (Fogg et al., 1973). This capacity enables cyanobacteria to play a very important role in hostile environments (Housman et al., 2006; Zielke et al., 2005).

In general, studies into an organism's atmospheric nitrogen fixation capacity have been done in a laboratory setting. Therefore, very little information is available about the in situ fixing behavior of organisms (Aranibar et al., 2003; Grimm and Petrone, 1997; Sivonen et al., 2007), and such information in cave settings has been found only in the study of Griffiths et al. (1987), for the genera Nostoc and Gloeothece.

Because certain factors affecting nitrogen fixation are sometimes irreproducible in the laboratory and there is hardly any information available about nitrogen sources in such adverse environments as cave settings, prompted us to undertake this study. This work is the first to present in situ nitrogen fixation data in the Scytonema mat communities growing in caves.

\section{Study Area}

Andragulla Cave (UTM 30SWH848264) is situated at an elevation of $1,200 \mathrm{~m}$ in the municipality of Moratalla, in the Region of Murcia in southeastern Spain. The climate of this region is Mediterranean, with certain continental characteristics and frequent frosts in winter. The mean annual rainfall is $451 \mathrm{~mm}$, and the average temperature is $16.3{ }^{\circ} \mathrm{C}$. The area is made up of finely stratified limestone with overlaying layers of differently colored loams.

The cave entrance (Fig. 1), faces northwest and measures $2 \mathrm{~m}$ high, $6 \mathrm{~m}$ wide, and $2 \mathrm{~m}$ long (deep). Its lack of depth means that it is not so isolated from external influences, and the microclimate in the cave is very similar

\footnotetext{
${ }^{1}$ Div. Botánica, Dpto. de Biología Aplicada, Universidad Miguel Hernández Avda, Universidad, s/n 03202 Elche, Alicante, Spain. aasencio@umh.es

${ }^{2}$ Div. Botánica, Dpto. de Biología Vegetal, Facultad de Biología, Universidad de Murcia, Campus de Espinardo.30100 Murcia, Spain.maboal@um.es
} 

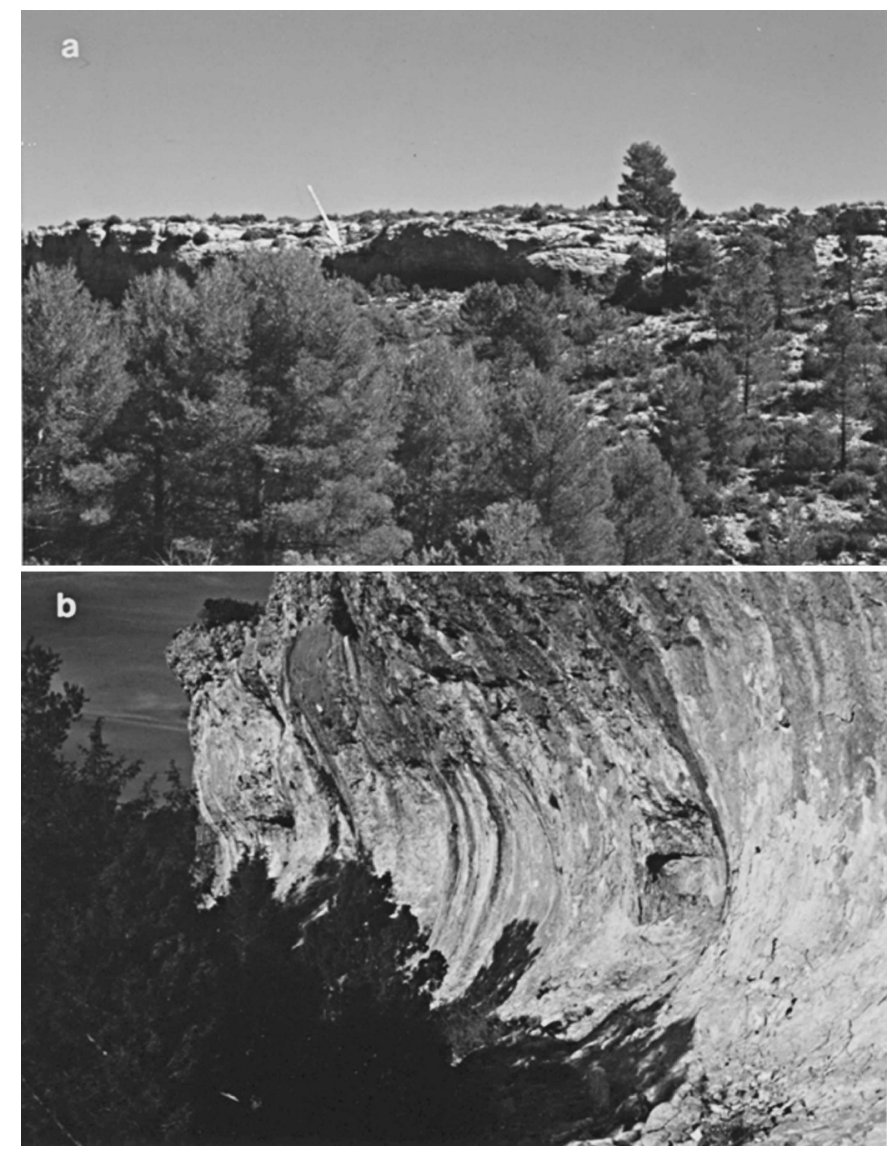

Figure 1. (a) Panoramic view of Andragulla cave in the Region of Murcia, southeastern Spain. (b) Walls of Andragulla Cave showing the cyanobacterial mats.

to that experienced externally. Inside the cave there are schematic-style cave paintings characterized by simple figures dating from the end of the Neolithic to the Iron Age (Beltrán-Martínez, 1983).

\section{Material And Methods}

So as to not damage the cave paintings on surrounding surfaces, great care was taken to collect material on the parts of the Andragulla cave wall where the Scytonema community grew (Asencio and Aboal, 2001). Samples were not hydrated, but were incubated in situ in triplicate in transparent and opaque vials to reproduce light and dark environments, respectively. Then $10 \%$ of the gas in these vials was replaced with acetylene using syringes inserted into the rubber stoppers (Hardy et al., 1973). Gas samples were taken at hourly intervals from sunrise to sunset on one day in winter and stored for laboratory analysis. Throughout the incubation period, the photon flux (Photosynthetically Active Radiation, PAR), air temperature, and relative humidity values were recorded hourly. An LI-1400 data-logger model (LICOR) with an LI-192 sensor and a Delta Ohm HD $8501 \mathrm{H}$ thermohygrometer



Figure 2. Light micrographs [scale bar $10 \mu \mathrm{m}$ ]. (a) Scytonema mirabile. (b) Gloeocapsa sanguinea.

were used. Electrodes were placed on the rock surface adjacent to the mats.

Nitrogen fixation in gaseous samples was quantified by acetylene/ethylene reduction assays (Peterson and Burris, 1976) analyzed in a Shimadzu GC-14A gas chromatograph.

\section{Results}

Nitrogen fixation was detected for the first time in a community formed by Scytonema mirabile (Fig. 2a) and Gloeocapsa sanguinea (Fig. 2b) growing as a brownishreddish mat in Andragulla Cave (Asencio and Aboal, 1996).

Nitrogenase activity during the day varied from 1.6 to $7.5 \mathrm{nmol} \mathrm{C}_{2} \mathrm{H}_{4} \mathrm{~m}^{-2} \mathrm{~s}^{-1}$ (Fig. 3). The nitrogenase activity remained low and constant in the morning from 8:00 a.m. to 11:00 a.m., at which time it began to increase, and it doubled by 1:00 p.m. to values of $3.5 \mathrm{nmol} \mathrm{C}_{2} \mathrm{H}_{4} \mathrm{~m}^{-2} \mathrm{~s}^{-1}$. This activity continued to increase until a maximum value of $7.5 \mathrm{nmol} \mathrm{C}_{2} \mathrm{H}_{4} \mathrm{~m}^{-2} \mathrm{~s}^{-1}$ was reached at 2:00 p.m., and then it started to drop, reaching a value of around $1 \mathrm{nmol}$ $\mathrm{C}_{2} \mathrm{H}_{4} \mathrm{~m}^{-2} \mathrm{~s}^{-1}$ at 3:00 p.m.

Journal of Cave and Karst Studies, August 2011 51 


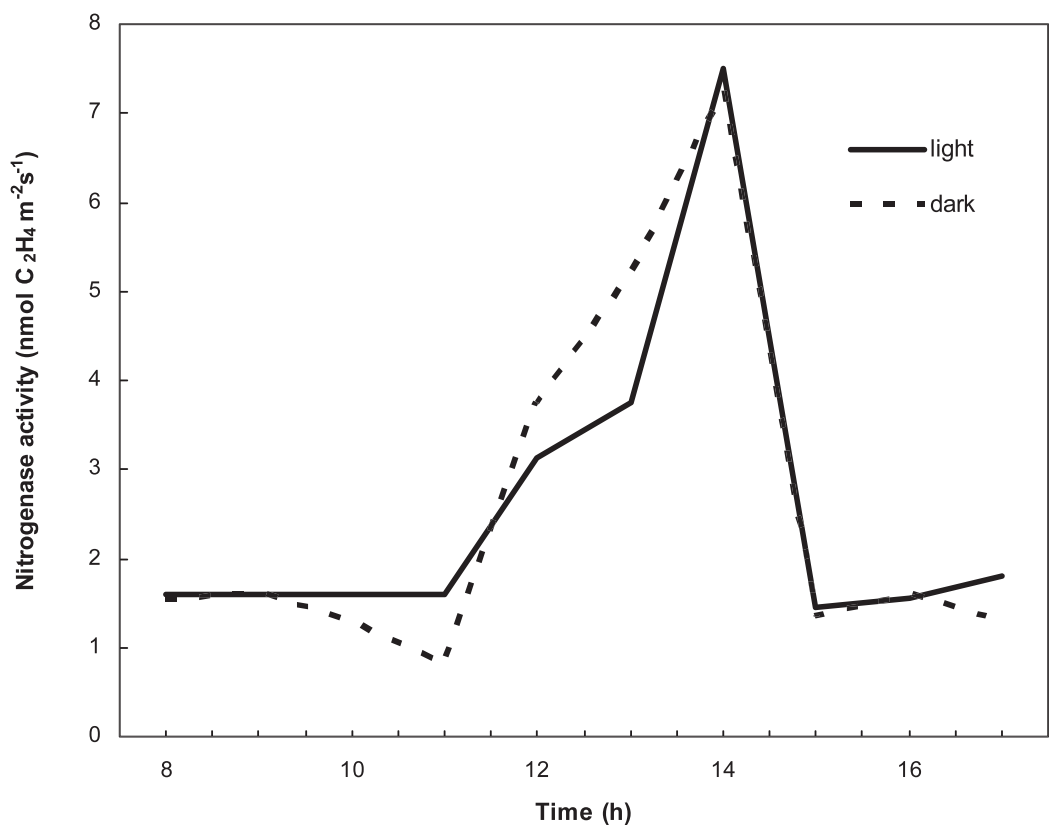

Figure 3. Nitrogenase activity by Scytonema mirabile (light) and Gloeocapsa sanguinea (dark) in Andragulla cave.

The photosynthetically active radiation in the Andra-

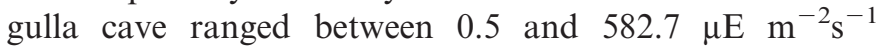
(Fig. 4). From 8:00 a.m. to 4:00 p.m., the values rose from 0.5 to $138.8 \mu \mathrm{E} \mathrm{m}^{-2} \mathrm{~s}^{-1}$, increasing to $582.7 \mu \mathrm{E} \mathrm{m}^{-2} \mathrm{~s}^{-1}$ at 5:00 p.m., and dropped later.

The maximum relative humidity value (Fig. 4) was $79.9 \%$, recorded at 8:00 a.m. and scarcely varying until noon, followed by a drop to the minimum value of $24.0 \%$ at 4:00 p.m. Afterwards, it began to rise once more.

The lowest temperature in Andragulla Cave was $1.5^{\circ} \mathrm{C}$, which was recorded in the morning at 8:00 a.m. After this time, it started to rise until it reached $4.7^{\circ} \mathrm{C}$, but started dropping again to reach $1.5^{\circ} \mathrm{C}$ at 11:00 a.m. Later, it rose, and the highest temperature of $20.3{ }^{\circ} \mathrm{C}$ was recorded at 4:00 p.m., after which it began to fall again (Fig. 4).

Nighttime nitrogen fixation varied from 0.8 to $7.3 \mathrm{nmol}$ $\mathrm{C}_{2} \mathrm{H}_{4} \mathrm{~m}^{-2} \mathrm{~s}^{-1}$ (Fig. 3). At 8:00 a.m., a value of $1.53 \mathrm{nmol}$ $\mathrm{C}_{2} \mathrm{H}_{4} \mathrm{~m}^{-2} \mathrm{~s}^{-1}$ was recorded, which rose to $1.61 \mathrm{nmol} \mathrm{C}_{2} \mathrm{H}_{4}$ $\mathrm{m}^{-2} \mathrm{~s}^{-1}$ at 9:00 a.m. From that time, it started to drop and reached its lowest value of $0.8 \mathrm{nmol} \mathrm{C}_{2} \mathrm{H}_{4} \mathrm{~m}^{-2} \mathrm{~s}^{-1}$, recorded at 11:00 a.m. Afterwards, it rose to reach the highest value of $7.3 \mathrm{nmol} \mathrm{C}_{2} \mathrm{H}_{4} \mathrm{~m}^{-2} \mathrm{~s}^{-1}$ at 2:00 p.m., when it started to drop again.

\section{DisCUSSION}

The nitrogenase activity recorded for the community formed by Scytonema mirabile and Gloeocapsa sanguinea in Andragulla Cave during the day ranged from 1.4 to $7.5 \mathrm{nmol} \mathrm{C}_{2} \mathrm{H}_{4} \mathrm{~m}^{-2} \mathrm{~s}^{-1}$. These values are very similar to those recorded in Cathole Cave (USA) for Nostoc sp., which reached a maximum value of $8.3 \mathrm{nmol} \mathrm{C}_{2} \mathrm{H}_{4} \mathrm{~m}^{-2} \mathrm{~s}^{-1}$ (Griffiths et al., 1987).
If we compare the nitrogenase activity registered for Scytonema mirabile and Gloeocapsa sanguinea in Andragulla Cave with the mean value of $28.2 \mathrm{nmol} \mathrm{C}_{2} \mathrm{H}_{4}$ $\mathrm{m}^{-2} \mathrm{~s}^{-1}$ recorded on the crusts of Scytonema sp. in semiarid areas of the USA (Jeffries et al., 1992), we find an important difference, basically owing to the fact that the latter samples had been previously rehydrated, as opposed to the limited natural moisture in the Andragulla Cave samples. This fact, along with the various experiments carried out by Renaut et al. (1975), who recorded higher nitrogenase activity values if samples had been moistened prior to nitrogen fixation, confirmed the importance of a high relative humidity in the nitrogenfixation process.

Here we can observe how nitrogenase activity increased as the light intensity in the study area grew, which is in agreement with Dodds (1989). It grew to such an extent that irradiance was so high that it inhibited the activity of this enzyme. Its activity resumed afterwards, however, when light intensity diminished at sunset.

Nighttime ethylene production differed only slightly from that achieved in the daytime, with values between 0.8 and $7.3 \mathrm{nmol} \mathrm{C}_{2} \mathrm{H}_{4} \mathrm{~m}^{-2} \mathrm{~s}^{-1}$, which are very similar to those recorded in Cathole Cave (USA) for Gloeothece sp., which reached a maximum of $7.9 \mathrm{nmol} \mathrm{C}_{2} \mathrm{H}_{4} \mathrm{~m}^{-2} \mathrm{~s}^{-1}$ (Griffiths et al., 1987). This finding could indicate the capacity of Gloeocapsa sanguinea to fix nitrogen aerobically and in the dark, as shown in other species of this genus (Zhou and Chen, 1991).

The protection mechanisms that Gloeocapsa sanguinea may have against the effect of oxygen remain unknown. The temporal distributions of oxygenic photosynthesis and nitrogen fixation could be one of the mechanisms that 


\section{ANDRAGULLA cave}


Figure 4. Photosynthetically active radiation (PAR), temperature, and relative humidity from sunrise to sunset in Andragulla cave at a cyanobacterial mat of Scytonema mirabile and Gloeocapsa sanguinea.

Gloeocapsa sanguinea uses to protect the nitrogenase enzyme from inactivation by oxygen. Indeed, during the nighttime, when the photosynthetic oxygen concentration decreases, the atmospheric nitrogen activity fed by aerobic respiration takes place, thus allowing nitrogenase activity to occur exclusively during the dark period. Another strategy could be the existence of a so-called pod-like structure that surrounds each cell and the cenobiums that may act as a physical barrier to prevent the entrance of atmospheric gases, as in Gloeothece (Meeks et al., 1978).

Minimum temperature values inhibited nitrogenase activity in the dark, which was clearly shown with Gloeocapsa sanguinea as ethylene production abruptly lowered with a drop in temperature, but increased when higher temperatures were recorded. This pattern coincides with the work of Griffiths et al. (1987) conducted in
Cathole Cave (USA), where nitrogenase activity was completely blocked in the coldest winter months.

The environmental parameters involved in nitrogen fixation studied in Andragulla Cave acted differently depending on whether daytime fixation or nighttime fixation was underway. From this, we may deduce that light intensity actively influences daytime fixation, temperature affects night-time fixation, and relative humidity acts with the same intensity on both.

Both the daytime and nighttime fixation values recorded for the first time in the community made up of Scytonema mirabile and Gloeocapsa sanguinea in Andragulla Cave are similar. We believe the presence of heterocysts is not an essential requirement for nitrogen fixation, and that non-heterocystic aerobic fixing organisms may contribute considerably to the overall nitrogen cycle in harsh environments such as cave entrances and other lighted areas.

\section{ACKNOWLEDGEMENTS}

We sincerely thank Dr. A. Morte for her help in the field and $\mathrm{H}$. Warburton for his assistance with the English version of the text.

\section{REFERENCES}

Asencio, A.D., and Aboal, M., 1996, Cyanophytes from Andragulla abrigo (Murcia, SE Spain) and their environmental conditions: Archiv für Hydrobiology/Algological Studies, v. 83, p. 55-72.

Asencio, A.D., and Aboal, M., 2001, Biodeterioration of wall paintings in caves of Murcia (SE Spain) by epilithic and chasmoendolithic microalgae: Archiv für Hydrobiology/Algological Studies, v. 103, p. $131-142$.

Aranibar, J.N., Anderson, I.C., Ringrose, S., and Macko, S.A., 2003, Importance of nitrogen fixation in soil crusts of southern African arid ecosystems: acetylene reduction and stable isotope studies: Journal of Arid Environments, v. 54, p. 345-358.

Beltrán-Martínez, A., 1983, El arte esquemático en la Península Ibérica: orígenes e interrelación: Bases para un debate: Zéphyrus, v. 36, p. $37-41$.

Dodds, W.K., 1989, Microscale vertical profiles of $\mathrm{N}_{2}$ fixation, photosynthesis, $\mathrm{O}_{2}$, chlorophyll a and light in a cyanobacterial assemblage: Applied Environmental Microbiology, v. 55, p. 882-886.

Fay, P., 1992, Oxygen relations of nitrogen fixation in cyanobacteria: Microbiological Reviews, v. 56, p. 340-373.

Fogg, G.E., Stewart, W.D.P., Fay, P., and Walsby, A.E., 1973, The BlueGreen Algae, London, Academic Press, 459 p.

Gallon, J.R., 1980, Nitrogen fixation by photoautotrophs, in Stewart, W.D.P., and Gallon, J.R., eds., Nitrogen Fixation, New York, Academic Press, p. 197-238.

Griffiths, M.S.H., Gallon, J.R., and Chaplin, A.E., 1987, The diurnal pattern of dinitrogen fixation by cyanobacteria in situ: New Phytologist, v. 107, p. 649-657.

Grimm, N.B., and Petrone, K.C., 1997, Nitrogen fixation in a desert stream ecosystem: Biogeochemistry, v. 37, p. 33-61.

Hardy, R.W.F., Burns, R.C., and Holsten, R.D., 1973, Applications of the acetylene-ethylene assay for measurement of nitrogen fixation: Soil Biology and Biochemistry, v. 5, p. 47-81.

Housman, D.C., Powers, H.H., Collins, A.D., and Belnap, J., 2006, Carbon and nitrogen fixation differ between successional stages of biological soil crusts in the Colorado Plateau and Chihuahuan Desert: Journal of Arid Environments, v. 66, p. 620-634.

Jeffries, D.L., Klopatek, J.M., Link, S.O., and Bolton, H. Jr., 1992, Acetylene reduction by criptogamic crusts from a blackbrush 
In Situ nitrogen fiXation by Cyanobacteria at the Andragulla Cave, Spain

community as related to resaturation and dehydration: Soil Biology and Biochemistry, v. 24, p. 1101-1105.

Meeks, J.C., Wolk, C.P., Lockau, W., Schilling, N., Shaffer, P.W., and Chien, W.-S., 1978, Pathways of assimilation of $\left(\left[{ }^{13} \mathrm{~N}\right] \mathrm{N}_{2}\right.$ and $\left.{ }^{13} \mathrm{NH}_{4}^{+}\right)$ by cyanobacteria with and without heterocysts: Journal of Bacteriology, v. 134, p. 125-130.

Peterson, R.B., and Burris, R.H., 1976, Conversion of acetylene reduction rates to nitrogen fixation rates in natural populations of blue-green algae: Analytical Biochemistry, v. 73, p. $404-410$.

Renaut, J., Sasson, A., Pearson, W., and Stewart, W.D.P., 1975, Nitrogenfixing algae in Morocco, in Stewart, W.D.P., ed., Nitrogen Fixation by Free-living Micro-organisms (IBP Handbook no. 6), Cambridge, Cambridge University Press, p. 229-246.
Sivonen, K., Halinen, K., Sihvonen, L.M., Koskenniemi, K., Sinkko, H., Rantasärkkä, K., Moisander, P.H., and Lyra, C., 2007, Bacterial diversity and function in the Baltic Sea with an emphasis on cyanobacteria: Ambio, v. 36, no. 2-3, p. 180-185.

Walsby, A.E., 1985, The permeability of heterocysts to the gases nitrogen and oxygen: Proceedings of the Royal Society B, v. 226, p. 345-366.

Zhou, H., and Chen, T., 1991, The isolation, purification and efficiency of nitrogen fixation for unicellular cyanobacteria Gloeocapsa spp: Acta Microbiologica Sinica, v. 31, p. 405-409.

Zielke, M., Solheim, B., Spjelkavik, S., and Olsen, R.A., 2005, Nitrogen fixation in the high Arctic: role of vegetation and environmental conditions: Arctic, Antarctic and Alpine Research, v. 37, no. 3, p. $372-378$. 